Беларускі дзяржаўны ўніверсітэт культуры і мастацтваў

Факультэт інфармацыйна-дакументных камунікацый

Кафедра беларускай філалогіі і сусветнай літаратуры

tel.: +375-17-222-83-71

e-mail: klimau@mail.ru

\title{
Кампетэнцыя князя Андрэя Курбскага як перакладчыка
}

Ключавыя словы: пераклад, кампетэнцыя ў мовах, князь Андрэй Курбскі.

Амаль усё, што цяпер вядома пра перакладчыцкія ідэі і здольнасці князя Андрэя Курбскага, маскойскага арыстакрата, эміграваўшага у 1564 г. у ВКЛ, паходзіць з яго лістой і прадмой да перакладных твораў. Але гэтыя крыніцы зараз выглядаюць даволі ненадзейна: ix сапраўднасць ў навуцы была аспрэчана (лісты) ці патрабуе верыфікацыі (прадмовы). Так, у 1970-х гг. Э. Кінан выказаў абгрунтаваны сумнеў у аўтарстве Курбскага наконт шэрагу працяглых лістой, адрасаваных у Масковію, якія да таго лічыліся арыгінальнымі творамі кзязя [Keenan 1971; Keenan 1974; Keenan 1978; Keenan 1998]. Прыналежнасць Курбскаму многіх перакладаў (іх агляд гл.: [Беляева 1984]) выклікае сумнеў у сучасных даследчыкаў [Калугин 1998, 77-86, 286; Ерусалимский 2001, 305, 308-310]. Яны абмяжойваюць кола перакладаў, што належалі Курбскаму, значна меншым лікам. У гэты лік не трапілі некаторыя пераклады, што маюць прадмовы, напісаныя ад імя

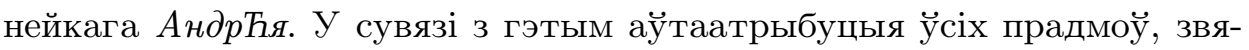
заных з Курбскім, губляе сваю доказную моц - яны маглі быць свядома фальсіфікаваныя ці памылкова прыпісаныя яму. Вядомы таксама шэраг актавых і некалькі наратыўных крыніц, якія асвятляюць пераважна штодзённы побыт князя, але вельмі сціпла характарызуюць 
яго інтэлектуальныя заняткі. Таму кола надзейных крыніц, што могуць сведчыць пра такія заняткі, у дачыненні да Курбскага становіцца зусім нязначным. Тым не менш, сумненні ӱ аўтэнтычнасці яго лістой і прадмоў не могуць быць адхіленыя ці праігнараваныя, хаця б у мэтах навуковай аб'ектыўнасці, якая прымушае разгледзець усе падазрэнні наконт сапраўднасці і верагоднасці крыніц. Аднак дадзеная праца не накіравана на такое высвятленне, яе задача больш сціплая: аналіз дасяжных звестак пра перакладчыцкую капетэнцыю Курбскага, з улікам мэт і задач яго перакладчыкай дзейнасці наогул. Таму ў працы часова прымаецца, што лісты і прадмовы Курбскага сапраўдныя. Гіпотэза даследавання палягае хутчэй у дасягненні адваротнага, калі ўлік належных звестак 3 твораў Курбскага, што лічацца ў навуцы сапраўднымі, прывядзе да супярэчлівых ці парадаксальных высноў. Гэта дазволіць паставіць задачу для далейшага даследавання - цяпер ужо наконт аўтэнтычнасці перакладаў, прыпісаных яму.

На новай радзіме Курбскі прыкладна каля 1569 г. актыўна заняўся культурнай працай. Ён распачаў цэлую праграму па перакладзе на царкойнаславянскую мову некаторых рэлігійных і нават філасофскіх тэкстаў, якія здаваліся яму (i, напэўна, яго атачэнню) актуальнымі. Сваёй мэтай маскоўскі эмігрант зрабіў уздым духоўнасці, паглыбленне сапраўднай рэлігійнасці ў сучасным яму праваслаўным грамадстве, перш за ўсё ў Рэчы Паспалітай і Масковіі [Ерусалимский 2009, 54 і сн. 206], дзе карысталіся царкоўнаславянскай мовай - т. зв. Slavia Orthodoха. Сродкам для гэтага, на думку князя, мусіла стаць стварэнне поўных і дакладных перакладаў некаторых найбольш прэцэдэнтных рэлігійных твораў, важных для ўздыму асабістай рэлігійнасці як духавенства, так і ляікай. Магчыма, таксама ідэалагічныя атакі з каталіцкага і пратэстанцкага бакоў супраць царкойнаславянскай культуры і мовы, шчыльна звязанай з візантыйскім праваслаўем, прымусілі Курбскага абараняць і развіваць менавіта царкойнаславянскую традыцыю [Андреев 1873, 6-18; Bakus 1969, 48-50; Цеханович 1985, 15-17, 21; Ерусалимский 2009, 63].

Курбскі быў прыхільнікам традыцыйнай царкоўнай адукаванасці і грэка-візантыйскай вучонасці, а як маскоўскі выхадзень, ён не згаджаўся з ужыткам у духоўнай сферы іншай мовы, апрача царкоўнаславянскай. Здаецца, Курбскі быў адмоўна настроены супраць мясцовай «руськай» традыцыі, якую сустрэў на Беларусі і Украіне. У адным дакуменце 1571 г. ён нават падпісаўся па-латыні, для того иж сам по-руски писати невмею [Auerbach 1985, 375, 377-379 i Anm. 8, 9]. Гэта нарадзіла сумненні ў адукаванасці Курбскага [Auer- 
bach 1987, 15] і выклікала да жыцця падазрэнні, што арыстакрат Курбскі дыктаваў сваім сакратарам уласныя пераклады [Калугин 1998, 17-18]. 3 крыніц вядома, што ён умеў чытаць дакументы на «руськай» мове [Жизнь 1849 1, 5; Auerbach 1985, 375, 375, 378], а аднойчы ён распісаўся па-латыні кірылічнымі літарамі [Жизнь 1849 1, 36]. На думку В. Калугіна, такая пазіцыя Курбскага тлумачыцца снабізмам арыстакрата, ён не ўмеў пісаць скорапісам, якім былі напісаныя «руськія» акты таго часу (і якім карысталіся тагачасныя канцылярысты), але валодаў уставам і паўвуставам, а таксама лацінай [Калугин 1998, 19-23, 281]. Але ж яго толькі папрасілі падпісаць дакумент, і тут не мела значэння, як гэта зрабіць: па-руску ці па-царкойнаславянску, паўвуставам ці скорапісам [Auerbach 1985, 378-379; Epycaлимский 2001, 323-324]. Таму на думку К. Ерусалімскага, князь проста жадаў прадэманстраваць адданасць свайму новаму сюзерэну польскаму каралю [Ерусалимский 2001, 323-324; Ерусалимский 2009, 78-79, 311 і сн. 351]. Аднак сумнеўна, што ў тую эпоху палітычная лаяльнасць магла выражацца праз графіку літар (хутчэй гэта сведчыць пра культурную прыналежнасць), тым больш, што кароль наўрад ці чытаў той дакумент. Больш верагодна іншае меркаванне даследчыка: падобныя выказванні Курбскага наконт няведання ім той або іншай мовы - толькі тактычны прыём у час судовага працэсу [Ерусалимский $2009,79,81]$.

Цікава, што Курбскі, паводле яго карэспандэнцыі, падзяляў распаўсюджаныя сярод часткі праваслаўнага духавенства Рэчы Паспалітай погляды пра высокую сакральную вартасць царкоўнаславянскай мовы: вождЋленный и любимый праотеиъ твоихъ прирожденный языкъ Словенскій [РИБ, 412]. Сваім духойным зместам гэтая мова пераўзыходзіць польскую барбарію і лаціну, на якія немагчыма добра перакласці творы св. айцоў: Сенсъ быти нћяко можетъ, но околичность слогънеи зһло будетъ далеко [РИБ, 413]. Разам з тым у лісце да вучня старца Арцемія князь адзначаў заняпад гэтай мовы: аще $u$ добуду грецкимъ умћющаго або латинскимъ, по словенскій не будутъ умћти [РИБ, 416]. Тут маскоўскі эмігрант хутчэй за ўсё меў на ўвазе людзей з заходняй адукацыяй у Рэчы Паспалітай, якія б ведалі яшчэ і царкоўнаславянскую мову. Ён прызнаваў, што на новай радзіме ў сувязі са сваёй працай исках мужей, словенским языком книжным добре умеющих, и не возмогох обрести [Архангельский 1888, 13; Kurbskij 1976, 6], искахъ помощи себћ, семо и овамо обращаяся, и никако же обрЋтохом [РИБ, 418]. Аднак патрэба ў такіх спецыялістах у ВКЛ наўрад ці была вострай. Напрыклад, калі Курбскі паслаў князю Аст- 
рожскаму свой царкойнаславянскі пераклад, той параіў яму перакласці твор лепшаго ради вьгразумения на польщизну [РИБ, 413].

Пры гэтым Курбскі прызнаваўся, што сам недастаткова ведае царкойнаславянскую мову. Нават збіраючыся перакладаць рэлігійныя творы, ён адзначаў недахоп уласнай кампетэнцыі ў ёй: бо не обвьлкли есмьи, яко азъ, тако князь Михаило, Словенску языку въ конецъ [РИБ, 418]. Праўда, тут можа мець месца этыкетнае самапрыніжэнне адрасанта (часткова абумоўленае жаданнем атрымаць у супрацоўнікі вучня старца Арцемія), паколькі потым ён згадаў кнігу нашего переводу, прызнаўшы, што адзін пераклад на гэтую мову ім усё ж быў выкананы.

Развіццё рэлігійнасці бачылася Курбскаму перш за ўсё за кошт стварэння новых перакладай на царкойнаславянскай мове ці аптымізацыю ўжо існуючых. Многія 3 іх былі выкананыя ці выпраўленыя не паводле грэчаскіх арыгіналаў, а 3 лацінскіх крыніц, вядомых у заходнееўрапейскіх выданнях, што пацвярджаецца і аналізам сучасных вучоных, і прызнаннямі самога Курбскага, зробленымі у яго карэспандэнцыі. Так, выкладаючы свае перакладчыцкія планы, ён пералічвае і купленыя з гэтай мэтай лацінскія выданні [РИБ, 417]. Аднак ці меў князь дастатковую адукацыю, каб самастойна выконваць падобную працу?

Э. Кінан негатыўна адказваў на гэтае пытанне, не знайшоўшы надзейных крыніц наконт адукацыі князя [Keenan 1971, 39, 98; Keenan 1978, 153]. Сапраўды, ніякіх дакументальных доказаў адукацыі Курбскага няма, апрача заяў самога князя, выказаных у яго лістах і прадмовах. На іх падставе даследчыкі часам робяць далёкасягаючыя высновы. 3 фразы ў прадмове да «Новага Маргарыту» Прочитах, разсмотрях Физические и обучахся и навыках етических, коя в собе замыкает ... естественную философию [Сказания 1833, 273; Kurbskij 1976, 4адв.] некаторыя выводзяць, што Курбскі вывучай працы антычных аўтараў, у прыватнасці, «Фізіку» і «Нікамахаву этыку» Арыстоцеля [Гаврюшин 1986, 211, 214; Калугин 1998, 70, 100], што занадта смела. На якіх мовах ён мог чытаць гэтыя творы? У царкоўнаславянскіх ці польскіх перакладах іх на той час не было, а выкарыстанне лацінскіх крыніц патрабуе добрага ведання лаціны, што у্у выпадку Курбскага вельмі сумнеўна (хаця б прымаючы у разлік памылкі, выяўленыя вучонымі $\breve{y}$ яго перакладах). Раней даследчыкі казалі толькі пра знаёмства князя з гэтымі творамі, не больш за тое [Ясинский 1889, 78]. Веданне лаціны знаходзіцца ў відавочнай супярэчлівасці з яго прыхільнасцю да традыцыйнай царкоўнаславяншчыны і праваслаўнай спадчыны. 3 ін- 
шага боку, з гэтым кантрастуе рэнесансавы погляд Курбскага на рыторыку, логіку, філасіфію, палітыку, што прачытваецца у яго творах [Freydank 1988; Ерусалимский 2009, 287], як і сам факт перакладу ім некалькіх фрагментаў з Цыцэрона.

Застаецца няясным, як і дзе маскавіт Курбскі мог здабыць веданне класічных моў. У Масковіі ён мог атрымаць толькі традыцыйную і несістэмную царкоўную адукацыю [Ясинский 1889, 77, 80-81], якая на той час цалкам унікала лаціны, а веданне грэчаскай мовы там было ўсё ж выключнай рэдкасцю. Праўда, даследчыкі лічаць, што настаўнікам Курбскага мог быць Максім Грэк [Ясинский 1889, 82-86; Харлампович 1900, 214], які навучыў князя грэчаскай мове, хаця ніякіх доказаў гэтаму няма (сам Курбскі мог з ім сустрэцца у 1553 г. хіба што на кароткі час). Аднак маскойскі арыстакрат нават з гэтага, здаецца, не скарыстаў: у сваёй карэспандэнцыі з ВКЛ ён неаднаразова скардзіўся (магчыма, не без некаторай этыкетнасці), што дрэнна ведае царкоўнаславянскую мову і таму патрабуе дапамогі вопытных кніжнікаў. Таму яшчэ менш падстаў меркаваць, што князь вынес са сваёй радзімы кампетэнцыю у грэчаскай мове (бо у такім выпадку бессэнсойна перакладаць з лацінскіх перакладаў візантыйскіх аўтараў, якія і на Захадзе публікаваліся на грэчаскай мове, а дастаць іх там было, напэўна, не нашмат цяжэй за лацінскія).

У любым выпадку, менавіта эміграцыя дала Курбскаму магчымасць даступіцца да лаціны. Ён паведамляе, што на Валыні браў урокі лацінскай мовы (а таксама філасофіi) у нейкага маладога бакалаўра Амброжыя (відаць, каталіка), зело въ писаніях искусна и верхъ философіи внЋшныяя достигша [Kurbskij 1976, 5адв., 7]. I. Аўэрбах атаясаміла гэтую асобу з гадаванцам Кракаўскага ўніверсітэта, што паводле дакументаў меў імя Ambrosius Szadkovius i у 1569 г. скончыў філасофскі факультэт з вучонай ступенню бакалаўра [Auerbach 1985, 136, 379-380, 399-400; Auerbach 1987, 17-18; Калугин 1996, 43-44]. Іншыя даследчыкі без асаблівых падстаў бачылі у ім Аброзія Бражоўскага, які зрабіў пераклад «Хронікі» Мацэя Стрыйкойскага на руськую мову [Андреев $1873,28]$. Аднак наколькі добра звычайны бакалаўр (нават калі і дапусціць, што вельмі здольны) у тых умовах мог навучыць дарослага чалавека зусім нязвыклай для яго мове, даволі складанай і кніжнай? Пытанне гэтае пакуль застаецца без адказу з боку навукойцаў. А адказ на яго тым больш патрэбны, што сам князь, як вынікае з яго твораў, варожа ставіўся да заходняй «барбарыі» (гл. вышэй).

У сваіх доказах даследчыкі часам спасылаюцца на даволі ненадзейныя крыніцы - сведчанні польскіх геральдыстаў XVI-XVII стст. Бар- 
таш Папроцкі у сваім гербоўніку «Herby Rycerstwa Polskiego» (1584) згадаў навучанне князя латыні, які maż byt dowcipny, з чаго даследчыкі робяць глыбокадумныя высновы пра вучонасць Курбскага [Ерусалимский 2009, 82-83, 84, 93]. Шымон Акольскі у сваім гербоўніку «Orbis Poloni» (1641) адзначыў вялікі розум маскавіта, што ў сталым веку вывучыў лацінскую мову [Бартошевич 1881, 66; Калугин 1998, 32-33; Ерусалимский 2009, 83, 311]. Аднак гэты геральдыст асабіста ведаць Курбскага не мог і хутчэй за ўё запазычыў свае звесткі з нейкай крыніцы (паведамленне выглядае як анекдот), таму звесткі Акольскага могуць быць разгледжаныя як міфалагічныя [Филюшкин 2008, 10]. Гэтак сама з чужых вуснаў маглі паходзіць і звесткі Папроцкага. Ва ўсялякім выпадку, з гэтых сведчанняў не вынікае, як Курбскі выкарыстоўваў свае лінгвістычныя веды - а яны маглі быць павярхойнымі (не кажучы ўжо пра тое, што князь (ці яго атачэнне) у мэтах рэкламы мог распаўсюджваць у арыстакратычным асяроддзі Рэчы Паспалітай перабольшаныя звесткі пра ўласную мойную кампетэнцыю).

3-за адсутнасці пэўных сведчанняў застаецца толькі меркаваць, што Курбскі у свае 40 гадоў здолей авалодаць лацінай у дастатковай ступені, каб перакладаць лацінскі тэкст ці, па меншай меры, кансультавацца з ім, часткова разумеючы сэнс пры перакладзе. Аднак ці дастаткова гэтага, каб адэкватна перакладаць складаныя тэалагічныя і філасофскія тэксты на царкойнаславянскую мову (якой такі перакладчык сам валодаў незадавальняюча)? Здаецца, не. Пры гэтым сам Курбскі прызнаўся, што лаціна далася яму не лёгка: ён вывучаў яе не мало лет, со многими труды [РИБ, 416-417]. Т. ч., лінгвістычная падрыхтоўка князя выглядае даволі сумнеўна. Вядома, што адзін яго пераклад нейкі крытык похулил, што моцна абурыла князя [РИБ, 411-114].

У сваім жыцці князь цікавіўся царкойнай кніжнасцю і духоўнымі пытаннямі - ад яго ацалелі кнігі, што былі затым перададзеныя нашчадкамі у манастыр [Ерусалимский 2009, 90-91]. 3 карэспандэнцыі Курбскага вынікае, што яшчэ ў маскоўскі перыяд князя суправаджалі розныя тетради, списки, столбиьл, листки - розныя запісы, якія ён вёў сам ці рабіӱ з іншых крыніц; гэтая асаблівасць захоўвалася і ў яго эмігранцкі перыяд. У многіх сваіх допісах ён просіць прыслаць яму кнігі або рукапісы ці паведамляе пра перасылку тэкстаў са свайго боку, абмяркоўвае тыя ці іншыя творы або кнігі. Курбскі таксама шмат разоў з пашанай згадваў Максіма Грэка (каля 1475-1556), візантыйскага грэка-эмігранта з Захаду ў Маскве (дарэчы, канвертыта 3 ка- 
таліцызму ӱ праваслаўе), і імкнуйся выставіць сябе ўдзячным вучнем таго [Ясинский 1889, 85; Пыпин 1894; Соболевский 1903, 279-282; Калугин $1998,47-48,77-78,102,132,258]$. Аднак усяго гэтага наўрад ці дастаткова, каб быць перакладчыкам складаных тэалагічных тэкстаў з класічных мой. Таму больш апраўдана лічыць удзел князя ў справе рэлігійных перакладаў не прамым, а апасродкаваным - у выглядзе рэдагавання ці ідэйнага кіраўніцтва. Менавіта да такой думкі схіляюцца сучасныя даследчыкі [Калугин 1998, 131].

Магчыма, Курбскі не проста прыцягвай памагатых да сваёй перакладчыцкай працы, але і выкарыстойваў іх працу, прыпісваючы сабе іх здабыткі. Відаць, яна аплачвалася князем, што давала яму юрыдычную падставу і маральнае апраўданне для прыўласнівання вынікаў чужой інтэлектуальнай працы (гэта было тыпова для той эпохі, з яе неразвітымі або нігілістычнымі ўяўленнямі пра аўтарскае права і інтэлектуальную ўласнасць); гэта вельмі верагодна $\ddot{y}$ выпадку адносін арыстакрата з прасталюдам ці беднай шляхтай. Сапраўды, нярэдка Курбскі адзначае ўдзел іншых асоб у сваёй перакладчыцкай працы [Калугин 1998, 32-33], у сувязі з чым вучоныя ӱжо з ХIX ст. гавораць пра цэлы гурток Курбскага $\breve{y}$ Мілянавічах. У адной са сваіх прадмой ён паведамляў, што перакладаў с помошники моими, ученьми мужеми, искусньми толковники в римской беседе [Архангельский 1888, 11, сн. 1; Kurbskij 1976, 5]. Маючы сродкі, князь, сапраўды, мог прыцягваць да працы самых розных спецыялістаў, якіх толькі можна было адшукаць у тых мясцінах.

Аднак у такім выпадку ӱзнікае пытанне: наколькі сапраўды належаць Курбскаму пераклады, што прыпісаны яму? Калі працу выконваў не ён, а іншая асоба або нейкі гурток (склад і заняткі якога, дарэчы, няпэўныя), то што разумеецца ў такім выпадку пад перакладамі Курбскага? Калі ён толькі рэдагаваў пераклады, то як адрозніць яго працу ад працы іншых перакладчыкаў? I наколькі значнай была такая рэдактура (яна магла быць і павярхойнай)? А калі ён не рабіў нават гэтага, а толькі ўхваляў выбар крыніц ці выкананне таго або іншага перакладу (магчыма, проста аплочваў яго), то як можна наогул казаць пра пераклад Курбскага (і тым больш пра яго перакладчыцкую тэхніку)? На жаль, усе гэтыя пытанні навукоўцамі або не ставяцца, або пакідаюцца без адказу. Між тым нават моўная кампетэнцыя князя застаецца няпэўнай, у сувязі з чым разважанні пра перакладчыцкую дзейнасць Курбскага выглядаюць зусім спекуляцыйна. Застаецца толькі шкадаваць, што многія даследчыкі не звяртаюць увагі на падобныя праблемы у справе аўтэнтычнасці перакладай Курбскага. 
Праведзены разгляд паказаў, што калі цалкам давяраць творам Курбскага, іх характарыстыкам перакладчыцкай дзейнасці кня3я, то можна прыйсці да нечаканай высновы, што ўласна сам Курбскі, напэўна, не з'яўляецца перакладчыкам. Здольнасць князя выканаць пераклады з лацінскай мовы выглядае сумнеўна, як і яго дастатковая кампэтэнцыя у царкойнаславянскай мове, на якую рабіліся такія пераклады. У сувязі з гэтым варта выказвацца пра перакладчыкую дзейнасць Курбскага вельмі абачліва. Таксама заслугойвае самага ўважлівага разгляду пытанне прыналежнасці яму перакладаў, не выключаючы тут нават найбольш сапраўдных.

\section{Літаратура}

Андреев В., 1873, Очерк деятельности князя А. М. Курбского на защиту православия в Литве и на Волыни, Москва.

Архангельский А.С., 1888, Очерки из истории западно-русской литературы XVI-XVII вв.: Борьба с католичеством и западно-русская литература конца XVI - первой половинь XVII в., приложение, Москва (Чтения в Обществе истории и древностей российских, 1888, кн. 1, отд. 1).

Бартошевич Ю., 1881, Князь Курбский на Вольини, "Исторический вестник", nr 9 , c. $65-85$.

Беляева Н.П., 1984, Материальг к указателю переводных трудов А. М. Курбского, [в:] Древнерусская литература: Источниковедение, сборник научных трудов, отв. ред. Д. С. Лихачев, Ленинград, с. 115-136.

Гаврюшин Н.К., 1986, Научное наследие А. М. Курбского, [в:] Памятники науки и техники: 1984 г., Москва, с. 210-236.

Ерусалимский К.Ю., 2001, Андрей Курбский и Иван Грозньий: борьба филологий (по поводу двух работ В.В. Калугина), "Russia Mediaevalis", Bd. 10, Hf. 1, c. 303-324.

Ерусалимский К.Ю., 2009, Сборник Курбского: Исследование книжной культурье, отв. ред. С. О. Шмидт. Москва, т. 1.

Жизнь князя Андрея Михайловича Курбского в Литве и на Вольєни: актьи, изданные временною комиссиею, высочайше учрежденною при Киевском военном, Подольском и Вольинском генерал-губернаторе, изд. Н. Д. Иванишев, 1849, т. 1, Киев.

Калугин В.В., 1998, Андрей Курбский и Иван Грозный: Теоретические взгляды и литературная техника древнерусского писателя, Москва.

Пыпин А.Н., 1894, Вопросы древне-русской письменности. 2: Максим Грек и князь Курбский, "Вестник Европы", т. 168 (342), nr. 4, с. 313-367.

РИБ, 1914: Сочинения князя Курбского, т. 1: Сочинения оригинальные, изд. Г. З. Кунцевичем, [в:] Русская историческая библиотека, т. 31. 
Сказания князя Курбского, изд. Н. Устрялов, 1833, т. 2, С.-Петербург.

Соболевский А.И., 1903, Переводная литература Московской Руси XIV-XVII веков: Библиографические материаль, С.-Петербург, (Сборник Отделения русского языка и словесности Императорской академии наук, т. 74, кн. 1); [repr.] 1966 The Hague.

Филюшкин А.И., 2008, Андрей Курбский, Москва. (Жизнь замечательных людей: серия биогр., вып. 1137).

Харлампович К.В., 1900, Новая библиографическая находка: переводная статья кн. А. М. Курбского «От другїе діалектики Ішана Спанинъбергера $\omega$ силогизме вытолковано», "Киевская старина" т. 70, nr. 7-8: июльавгуст, с. 211-224.

Цеханович А.А., 1985, А. М. Курбский в западнорусском литературном проиессе второй половинь XVI в., [в:] Книга и ее распространение в России в XVI-XVIII вв., сборник научных трудов, Ленинград, с. 14-24.

Auerbach I., 1985, Andrej Michajlovič Kurbskij: Leben in den osteuropäischen Adelsgesellschaften des 16. Jahrhunderts, München.

Auerbach I., 1987, Russische Intellektuelle im 16. Jahrhundert: Andrej Michajlovic Kurbskij und sein Kreis, [in:] Kurbskij, Andrej Michajlovič: Novyj Margarit: Historisch-kritische Ausgabe auf der Grundlage der Wolfenbütteler Handschrift, hrsg. I. Auerbach, Bd. 3, Lf. 15, Gießen, S. 13-51 (Bausteine zur Geschichte der Literatur bei den Slawen).

Bakus O. P., 1969, A. M. Kurbsky in the Polish-Lithuanian State, "Acta Baltico-Slavica", vol. 6, p. 29-50.

Freydank D., 1988, Zwischen griechischer und lateinischer Tradition: A. M. Kurbskijs Rezeption der humanistischen Bildung, "Zeitschrift für Slawistik", Bd. 33, Hf. 6, S. 806-815.

Keenan E. L., 1971, The Kurbskii-Groznyi Apocrypha: The Seventeenth Century Genesis of the "Correspondence" attributed to Prince A. M. Kurbskii and Tsar Ivan IV, with an appendix by Daniel C. Waugh, Cambridge / Mass.

Keenan E. L., 1974, Reply, "Forschungen zur osteuropäischen Geschichte", Bd. 22, Hf. 4, p. 593-617.

Keenan E. L., 1978, Putting Kurbskii in His Place, or: Observations and Suggestions concerning the Place of the History of the Grand Prince of Muscovy in the History of Muscovite Literary Culture, "Forschungen zur osteuropäischen Geschichte", Bd. 24, S. 131-161.

Keenan E., 1998, Response to Halperin, «Edward Keenan and the Kurbskii-Groznyi Correspondence in Hindsight», "Jahrbücher für Geschichte Osteuropas" (N. F.), Bd. 46, Hf. 4, p. 404-415.

Kurbskij A.M., 1976, Novyj Margarit: Historisch-krititsche Ausgabe auf der Grundlage der Wolfenbütteler Handschrift, hrsg. I. Auerbach, Gießen, Bd. 1, Lf. 1 (Bausteine zur Geschichte der Literatur bei den Slawen, Editionen 4, Bd. 9). 


\title{
COMPETENSE OF THE PRINCE ANDREY KURBSKY \\ AS A TRANSLATOR
}

\author{
S U M M A R Y
}

Various aspects of language capabilities of the famous Moscow aristocrat who emigrated to the Polish-Lithuanian Commonwealth in the 1560th is considered in the article. For not clear reasons which seem to be obvious for many scientists the prince turned to the translations of religious collections from Latin into Old Church Slavonic. However, language ability of Kurbsky seems to be insufficient for such occupation. Therefore there is a reasonable suspicion that these translations were carried out by the employed people, and the prince only appropriated fruits of their works. Thus it should to operate extremely carefully with expressions as "Kurbsky's translations" - perhaps, there are only a metaphor which is perceived too literally by some myopic researchers. 